\title{
9
}

\section{The Future of Work in Africa}

\begin{abstract}
In this chapter, Cilliers addresses the challenge of widespread unemployment in Africa, and how trends collectively labelled as the 'future of work' could unfold on the continent. It describes the differences between the ways in which Africa will likely experience the effects of automation and digitisation on the labour market, and argues that the fourth industrial revolution is less a threat to jobs in Africa than in developed economies. Nevertheless, clear action is needed. Using Ghana as an example, the chapter explores innovative approaches to expanding inclusion in the formal sector, including enabling policies for financial inclusion and increased revenue collection. In addition, it speaks to Africa's readiness to benefit from the emergent 'gig economy', and other forms of labour flexibilisation.
\end{abstract}

Keywords Unemployment - Gig economy - Flexible labour · Future of work · Automation - Digitisation

\section{Learning Objectives}

- Explain whether the formal or informal sector is dominant in Africa and why

- Explain the degree to which automation poses a challenge to employment in Africa

- Recognise examples of policy interventions from the Ghana case study that could support more formalised work futures for Africa

- Define the 'gig economy' and explain why its prospects are different in Africa than Europe and other high-income regions. 
The International Labour Organization (ILO) estimates the 2018 unemployment rate for adults (aged 15 and older) in Southern Africa at 26\% making it the region with the highest unemployment rate globally. Unemployment in Northern Africa is at $12.5 \%$ and it is less than half that in Western, Central and Eastern Africa. Females struggle for employment in North Africa, however. Whereas the gap between males and females is below four percentage points in West, East, Central and Southern Africa, female unemployment in North Africa is significantly higher than for males. ${ }^{1}$ The reason for the large difference in male/female unemployment ratios relate to levels of education and the barriers placed in many, but not all, Muslim-dominated countries on female advancement.

The ILO finds that low-income Africa generally has the lowest levels of unemployment and upper-middle income the highest.

The reason for these somewhat counterintuitive findings is that the ILOs definition of employment includes employment in the informal sector in its estimations of work. ${ }^{2}$ Employment data therefore would include an executive of a company who may be earning a million dollars a year and a teacher in the Democratic Republic of the Congo who earns US $\$ 100$ per month. It also includes a street vendor who sells packets of peanuts by the side of the road who may be earning 20 or 30 cents per day.

Previous chapters have already pointed to the dominance of the informal sector in Africa. On much of the continent the actual meaning of employment - a situation of having paid work or earning an income-therefore means earning something, anything, but seldom a living wage. Hence the ILO finds that almost 250 million persons in employment survive in extreme or moderate poverty—a number that is expected to rise annually by 4 million as the working age population increases. ${ }^{3}$

Many people in the informal sector live below or just above rates of extreme poverty. In the absence of a social net, employment in the informal sector is better than no employment. Informal workers lack benefits such as health insurance, unemployment insurance and paid leave. Most informal workers, many of which are self-employed, need to work every day to earn

\footnotetext{
${ }^{1}$ Data from ILOSTAT.

${ }^{2}$ According to the International Labour Organization (ILO), a person is unemployed if he/she is not in employment, is actively seeking work, and is available to take up work. International Labour Organization, 2013. Resolution I Adopted at the 19th International Conference of Labour Statisticians. Geneva, ILO, 2018. Also ILO, Women and Men in the Informal Economy: A Statistical Picture, 3rd Edition. Geneva: International Labour Office, p. 49.

${ }^{3}$ International Labour Organization, 2018. World Employment and Social Outlook: Trends 2018. Geneva: International Labour Office, pp. 11-13. Moderate and extreme poverty would include the share of workers living in households with income or consumption per capita below US $\$ 3.10$ per day.
} 
their living and pay for their basic household necessities. Their lives are precarious and their ability to survive shocks such as lock-down strategies to prevent the spread of COVID-19 is therefore very limited.

While the informal sector provides employment for unskilled and undereducated individuals, employment in this context is clearly not 'decent work', which the ILO defines as including 'a fair income, security in the workplace and social protection for families.'

Estimates and even data from the field that purport to reflect the size of the informal sector and the contribution it makes to African economies differ widely. According to the International Monetary Fund (IMF) the informal sector is responsible for only around $16 \%$ of the gross domestic product (GDP) of the 35 member Organization of Economic Development (OECD) countries, all of which are high income, and around $38 \%$ in sub-Saharan Africa. ${ }^{5}$ According to the ILO, in 2016, 86\% of employment in Africa was in the informal sector ( $72 \%$ excluding agriculture), the highest globally. Informal employment outside the agricultural sector ranges from 34\% in South Africa to $90.6 \%$ in Benin. ${ }^{6}$

Within the IFs forecasting system, which models its estimates differently from either the IMF, OECD or the ILO, the informal sector contributes about $36 \%$ of the economy of low-income countries in Africa, $30 \%$ of lowermiddle-income countries and $15 \%$ of upper-middle-income countries. IFs also models the contribution of the informal sector to GDP in Africa which is at around $36 \%$ for low income, 30\% to low-middle income and $15 \%$ for upper-middle-income countries in 2018. See Fig. 9.1.

Whichever the most accurate, the various estimates reflect the fact that a larger portion of the economies of poor countries are informal compared to rich countries and many more people are employed in the informal sector in poorer countries than in wealthier countries. At low levels of development the informal sector provides an important means of survival for poor people. To this end, goal 8 of the Sustainable Development Goals (SDGs) explicitly refers to the formalisation of micro, small and medium-sized enterprises.

\footnotetext{
${ }^{4}$ International Labour Organization, 2019. Decent Work. [Online] Available at: https://www.ilo.org/ global/topics/decent-work/lang--en/index.htm.

${ }^{5}$ International Monetary Fund, 2017. Chart of the Week: The Potential for Growth and Africa's Informal Economy. [Online] Available at: https://blogs.imf.org/2017/08/08/chart-of-the-week-the-potential-forgrowth-and-africas-informal-economy/.

'International Labour Organization, 2018. Women and Men in the Informal Economy: A Statistical Picture, 3rd Edition. Geneva: International Labour Office, p. 3. International Labour Organization, 2018. World Employment and Social Outlook: Trends 2018. Geneva: International Labour Office, p. 14. The gender gap in informal employment in some parts of sub-Saharan Africa is more than $20 \%$ (the rate at which women are more unemployed than men) and increases amongst youth.
} 


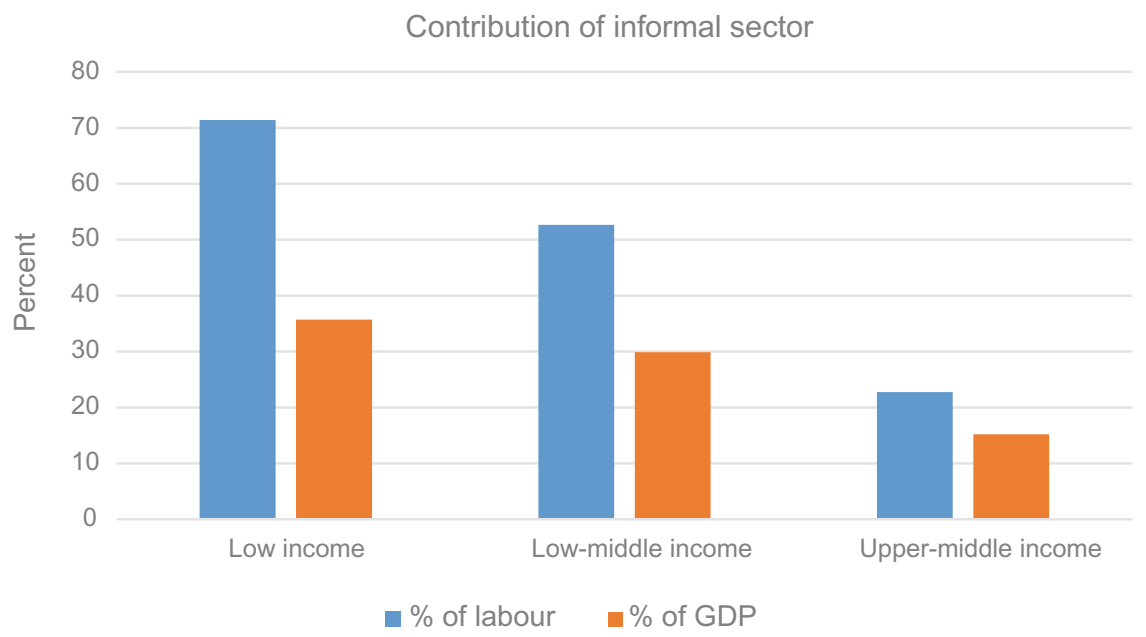

Fig. 9.1 2018 size of the informal sector in Africa by contribution to GDP and portion of labour (Source IFs v 7.45 initialising from ILO and IMF data)

While it is possible to imagine a growing informal economy alongside a growing formal sector, disproportionate growth in the informal sector hinders long-term inclusive growth. As a result, the reverse is more likely, and has also been observed historically, namely that the size of the informal sector generally declines as economies develop and grow.

It follows that generally, at low levels of development, the informal sector is generally significantly less productive than the formal sector. But typically the productivity gap between the informal and formal sector reduces as countries move up the income ladder and that, at higher levels of development, a large informal sector may often reflect a determined effort to avoid regulation. Generally, while informality is survivalist orientated at low levels of development, it is often more nefarious at higher levels of income. At higher levels of income, productivity in the informal sector could, in select instances, be comparable to that in the formal sector since the primary orientation here is often not survival but regulatory avoidance. Therefore, productivity in the informal sector in a high-income country such as Italy or Greece where the shadow or illicit economy is large, is not likely to differ much from that in the formal sector in these countries.

Irrespective of the level of development, generally, the existence of a large informal sector is costly for society and constrains sustainable development. People active in the informal sector do not contribute to direct taxes (since they are not registered to pay personal or company tax) but the informal sector still has to be served by police and requires infrastructure such as roads, 
water, sewerage, electricity and suchlike. The result is that a large informal sector places an additional burden on service delivery and congests public infrastructure while not contributing to either, except through unavoidable indirect taxes such as value-added and service taxes. This well-known negative drag that a large informal sector has is, however, balanced by the extent to which it soaks up people that would otherwise have no employment or opportunity.

Southern Africa has the smallest informal sector on the continent, with $40 \%$ in informal employment when the agricultural sector is included. ${ }^{7}$ The portion in the rest of the continent is much larger. In this subregion the informal sector therefore serves as less of a cushion to unemployment than elsewhere, reflected in the data from the ILO quoted at the start of this chapter that indicated its high levels of unemployment. With low levels of employment, inequality is generally high. There is probably a historical reason for this, since Southern Africa achieved independence most recently and the ruling parties (most of which were previously liberation parties heavily infused with ideological models that predate the collapse of the Berlin Wall) all stick to an ideology of economic centralism that offers little room for innovation and self-help. As a result, the economic emancipation of its majority peoples has not yet taken place. Government's promise to provide for their citizens but rarely do. Furthermore, in South Africa, the most recent country in the region to transition to majority rule, the previous system of mining, education and business was historically premised on the extraction of maximum profits and burdened the country with huge inequalities. With low levels of entrepreneurship and education, employment is particularly low and inequality is exceptionally high.

The ILO data on unemployment in Africa quoted at the start of this chapter is therefore actually quite misleading without appropriate context. Africa obviously has a huge unemployment challenge whichever way one looks at the matter, with the vast majority of its peoples forced to eke out a living in the informal sector. Estimates vary. For example the African Development $\mathrm{Bank}^{8}$ estimates that ten to twelve million youths, many of them educated, enter the African workforce annually, yet only three million formal

\footnotetext{
${ }^{7}$ And $36.1 \%$ when employment in agriculture is excluded. International Labour Organization, 2018. Women and Men in The Informal Economy: A Statistical Picture, 3rd Edition. Geneva: International Labour Office, p. 29. https://www.ilo.org/global/publications/books/WCMS_626831/lang--en/index. htm.

${ }^{8}$ African Development Bank, 2017. Growth and Job Creation: Policy Options for Pro-Employment Growth. Abidjan: AFDB.
} 
jobs are created each year. The International Monetary Fund (IMF) ${ }^{9}$ calculates that sub-Saharan Africa has to create 20 million formal jobs per year for the next two decades compared to an average of 9 million jobs added annually since 2000. The Africa Growth Initiative at the Brookings Institution ${ }^{10}$ believes that Africa needs to create 12-15 million jobs annually to absorb youth entering the labour market.

The job prospects along the Current Path forecast for Africa are not good. Between 2000 and 2014 formal employment in Africa expanded by less than $1.8 \%$ annually, ${ }^{11}$ but the labour force expanded by $2.6 \%$ per annum. Even at the robust $4.8 \%$ per annum average economic growth rate evident during these years, Africa's economy was not growing rapidly enough to create enough formal sector jobs.

\section{Trends in Employment}

Across all country income groups, the share of employment in services (the largest sector in most countries) is growing, and the share of employment in both agriculture and manufacturing employment is declining. This applies as much to Africa as to the rest of the world. Historically, technologydriven shifts in employment-for example, following the introduction of the personal computer-have created more jobs than they have destroyed. ${ }^{12}$ In this future the demand for skilled and semi-skilled workers is steadily increasing and that for unskilled labour (of which Africa has a large supply) decreases. As explained in Chapter 8, workers in much of Africa are moving out of subsistence agriculture in rural areas into low-end services in the informal sector in urban areas. Working conditions are generally worse in the services sector than in the manufacturing sector and only marginally better than in the subsistence agriculture sector.

\footnotetext{
${ }^{9}$ Abdychev, A., Alonso, C., Alper, E., Desruelle, D., Kothari, S., Liu, Y., Perinet, M., Rehman, S., Schimmelpfennig, A., and Sharma, P., 2018. The Future of Work in Sub-Saharan Africa. Washington: International Monetary Fund.

${ }^{10}$ Coulibaly, B. S, Gandi, D., and Mbaye, A. A., 2019. Job Creation for Youth in Africa: Assessing the Employment Intensity of Industries Without Smokestacks, 16 December 2019. [Online] Available at: https://www.brookings.edu/blog/africa-in-focus/2019/12/16/job-creation-for-youth-in-afr ica-assessing-the-employment-intensity-of-industries-without-smokestacks/.

${ }^{11}$ International Labour Organization, 2018. World Employment and Social Outlook: Trends 2018. Geneva: International Labour Office.

${ }^{12}$ Magwenthshu, Nomfanelo, Rajagopaul, Agesan, Chui, Michael, and Singh Alok, 2019. The Future of Work in South Africa-Digitisation, Productivity and Job Creation. McKinsey \& Company, September.
} 


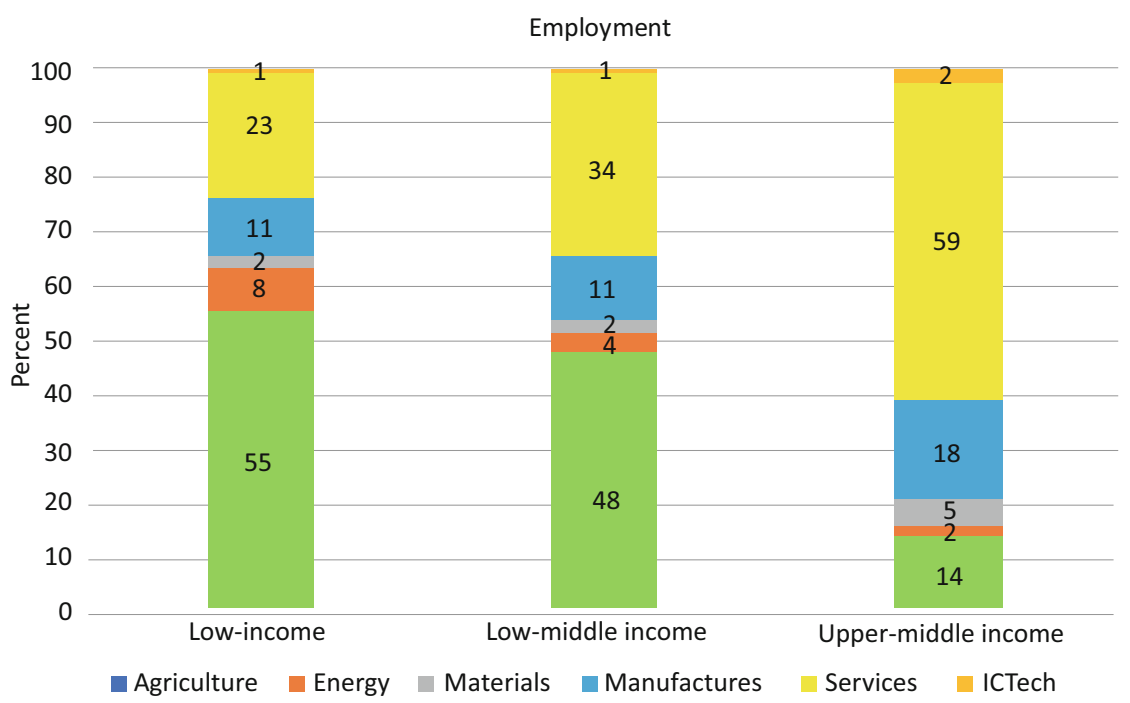

Fig. 9.2 2018 employment by sector for low, lower-middle and upper-middle-income Africa (Source IFs v 7.45 initializing from ILO and IMF data)

Currently most Africans are employed in the agricultural sector, which has roughly double the size of the labour force employed in the services sector, although, as noted in Chapter 8, the contribution of the services sector to GDP is substantially larger than the agricultural sector. Services, in turn, employ more than double the number of Africans that are employed in the manufacturing sector. Other sectors such as energy, materials and information technology employ significantly fewer people. Given the low levels of productivity in Africa's agricultural and large services sector, it comes as no surprise that Africa grows slowly.

Figure 9.2 presents the percent of employment for each of the six sectors within the IFs forecasting system for low, lower-middle and upper-middle Africa. Figure 9.3 presents the composition of low, lower-middle and uppermiddle-income Africa as the contribution of each of these six sectors to GDP. The data in both is an estimation from the IFs forecasting system for 2018.

At a first glance the employment contribution to a sector (Fig. 9.2), when read against the contribution of that sector to the economy (Fig. 9.3) would give an indication of productivity in each sector, but the relationship is complicated. For example, due to the large surplus of labour on the continent, economic growth in Africa is actually more employment intensive than it would otherwise be. ${ }^{13}$ It's often cheaper to employ more labour than to invest

\footnotetext{
${ }^{13}$ Kapsos, S., 2005. The Employment Intensity of Growth: Trends and Macroeconomic Determinants.
} Geneva: International Labour Office. 


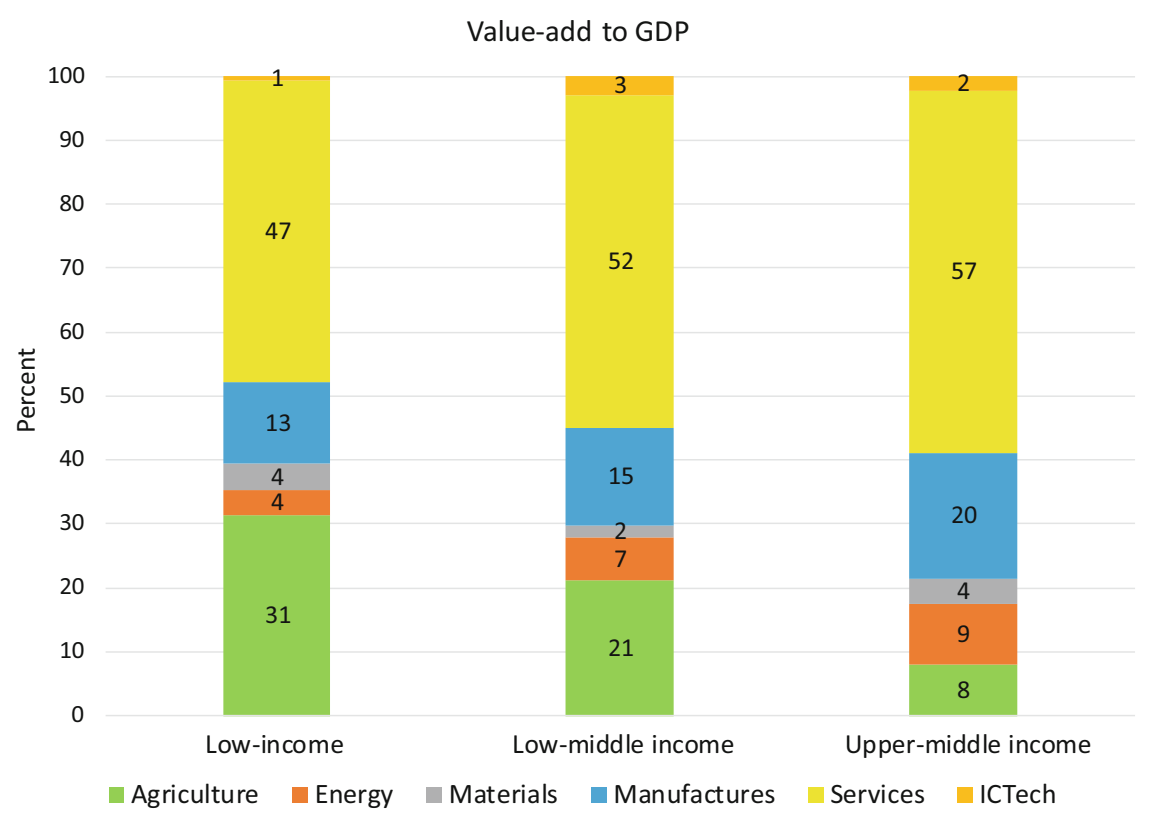

Fig. 9.3 2018 contribution of economic sectors to low, lower-middle and uppermiddle-income Africa (Source IFs v 7.45 initializing from ILO and IMF data)

in better systems or technology. Labour productivity is quite low due to the skills gap on the continent since investments in human capital, particularly in health (Chapter 3) and education (Chapter 6), are meagre.

The World Bank runs a Human Capital index that measures the lost productivity of the next generation of workers as a consequence of underinvestments in health and education. Sub-Saharan Africa can be found at the bottom of this index's global ranking. ${ }^{14}$

There is an unavoidable tension between employment-intensive growth as opposed to productivity-intensive growth. If an economy does not grow, the pressure for more output per worker will contribute to the steady decline in employment or a reduction in average remuneration. Typically that would happen through the process of automation. To grow employment Africans need to pay particular attention to measures that can unlock more rapid economic growth. This matter has already been discussed in previous chapters, pointing to the rather obvious fact that over long time horizons more rapid economic growth generally performs better in increasing employment than redistributive policies. Both are, of course, required. The often unspoken

\footnotetext{
14The World Bank, 2019. Human Capital Project. [Online] Available at: http://www.worldbank.org/ en/publication/human-capital.
} 
challenge is if it is politically possible for Africa to pursue the exploitative manufacturing labour practices through which other countries such as China and the Asian Tiger economies initially developed. I discuss this in Chapter 13 when dealing with governance, only to note that it is inherently more difficult for low-income democracies (of which Africa has a steadily increasing number) to institute the measures required for rapid economic growth than for authoritarian states. But then the latter is seldom focussed on implementing pro-growth policies in any case.

In Chapter $8 \mathrm{I}$ briefly examined the phenomenon of premature deindustrialisation (from already low levels) in Africa, and argued that it appears unlikely that Africa will be able to rapidly grow employment based on growth in manufacturing. The analysis presented there is that middle-income countries are experiencing declining shares of industry as a contribution to GDP and hence declining shares of industrial employment. This is occurring at an earlier stage of development compared to the history of today's developed countries. But because manufacturing is important in changing the productive structures within the entire economy, i.e. also within the agriculture and services sector, I also argued that African countries need to aggressively pursue industrialisation where this is possible. ${ }^{15}$

This trend of premature deindustrialisation complicates the potential impact of structural transformation towards more formal and less vulnerable employment in many African countries. In effect, the opportunity for industrialisation in Africa as a pathway to provide employment and productivity improvements seems to be slipping away. And since manufacturing is the single most important vehicle through which economies transition to higher productivity, the long-term impact of premature deindustrialisation could be debilitating. The conclusion, presented by many, is that African countries need to look elsewhere for growth, primarily towards tourism, agriculture, natural resource extracts and information technology services. ${ }^{16}$

The problem is that few of these sectors offer particularly exciting employment or productivity prospects. Africa is already overly dependent upon

\footnotetext{
${ }^{15}$ International Labour Organization, 2018. World Employment and Social Outlook: Trends 2018. Geneva: International Labour Office, p. 2.

${ }^{16}$ See, for example, the paper and presentation delivered by Joseph Stiglitz at the UNU-WIDER Development Conference in Helsinki, 13-15 September 2018. Beyond manufacturing export-led growth. [Online] Available at: https://www.wider.unu.edu/plenary-session/beyond-manufacturing-exp ort-led-growth. Also the Brookings Institution and UNU-WIDER work on Industries without Smokestacks: Industrialization in Africa Reconsidered. Page, J., Newfarmer, Richard S., Page, John, and Tarp, Finn, eds. 2018. Industries Without Smokestacks: Industrialization in Africa Reconsidered. Oxford University Press. https://www.wider.unu.edu/publication/industries-without-smokestac ks-2. Also Page, J. How Industries Without Smokestacks Can Address Africa's Youth Unemployment Crisis. [Online] Available at: https://www.brookings.edu/wp-content/uploads/2019/01/BLS 18234_BRO_book_007_CH3.pdf.
} 
natural resource extraction and very vulnerable to the associated swings in commodity prices. Commodity dependence is linked to political dysfunction and traps a country at the low end of the value chain. Tourism is employment intensive but not all countries have the offerings to be able to provide attractive packages or destinations. Nor does tourism offer the kind of learning-driven productivity improvements generally common to manufacturing. And then agriculture, where Africa has significant potential, automates even faster than industry. ${ }^{17}$

The African Agricultural Revolution scenario modelled in Chapter 5 is about the transformation of current traditional agriculture from subsistence to smallholder and eventually to be part of value chains that link smallholding farmers to retailers using ICT technology and a host of applications which becomes the glue holding this complex system together. In this manner, agriculture moves into manufacturing through agro processing with significantly higher levels of productivity.

In the short to medium term the African Agricultural Revolution scenario also has the potential to have a positive impact on creating employment, if not on the farm then certainly in the associated supply and distribution chain. The analysis in Chapter 8 illustrates that, over a time horizon of a decade and longer, a manufacturing growth path unlocks more rapid economic growth and eventually also provides more jobs than agriculture-although not initially. On top of this, improvements in productivity in agriculture are bound to reduce employment intensity as it introduces modern technology into the sector-although a growing agricultural sector would increase the number of jobs even as employment intensity declines. In other words, there is probably a limit on the potential of agriculture to provide the jobs that Africa so desperately needs, although it certainly would play an important role.

Chapter 8 therefore emphasised the importance of growing Africa's manufacturing sector. It does so not because of the (limited) potential of manufacturing to create jobs in the twenty-first century, but because of its importance in changing the productive structures of African economies and unlocking faster growth. Also important, although less explicit in that chapter, is the limits that Africa's higher-than-expected levels of democratisation play on a manufacturing led growth path. Whereas semi-democracies such as Ethiopia and Uganda can pursue the exploitative manufacturing labour practices that enable them to compete on cost with emerging Asia, it is doubtful if that

\footnotetext{
${ }^{17}$ Smith, N., 2019. Africa Could Become the New China If It Plays to Its Industrial Strengths. ThePrint. [Online] Available at: https://theprint.in/opinion/africa-could-become-the-new-china-if-itplays-to-its-industrial-strengths/245303/.
} 
is replicable in countries where democratic accountability is more deeply entrenched. More on this in Chapter 13.

The evidence is that a larger manufacturing sector has important enabling spillover effects. For example, it incentivises high-end services such as financial intermediation which is crucial for the development of the private sector and also encourages a more productive agricultural sector and consequently the transition into agro processing and agribusiness. These changes eventually produce higher growth rates and a more rapidly growing economy that in turn creates more jobs, though only in the medium to longer term.

The African Center for Economic Transformation in Ghana (ACET) is one of many institutions that advocates that both agriculture and light manufacturing are key requirements for the future. In its African Transformation Report 2017 it argues in favour of 'a dual-track to industrialisation. The one track should leverage their relative labor-abundance for labor-intensive and export-oriented light manufacturing, while the other should leverage their advantages in agriculture for globally competitive agriculturally based manufacturing. ${ }^{18}$ While an agricultural growth path is appropriate for lowincome countries, once these countries achieve middle-income status, a manufacturing growth path generally becomes more important.

However, as a contribution to GDP, or portion of the total economy, the services sector already dominates. In the Current Path forecast, the contribution from the services sector to Africa's economy steadily increases from its current $53 \%$ to almost $60 \%$ by 2040 while that of agriculture almost halves to $9 \%$. This is in line with a global trend towards more serviceoriented economies, with job growth particularly in non-routine work such as personal care services. Given the dominance of the services sector, most future employment growth on the African continent is set to come from here, which includes trade, transportation, finance and other commercial services.

These trends are confirmed by Louise Fox, Alun Thomas and Cleary Haines who write for the IMF that, 'Sub-Saharan Africa will not be able to transform through manufacturing as East Asia did over the past two decades'. ${ }^{19}$ According to them, the African growth experience over the last 35 years can, in general, be characterised as:

growth in capital-intensive resource- and energy-based industries - which in turn have not generated a sufficient number of jobs. Africa's manufacturing

\footnotetext{
${ }^{18}$ The African Center for Economic Transformation, 2017. African Transformation Report 2017: Agriculture Powering Africa's Economic Transformation. Ghana, p. 1. [Online] Available at: http://acetforaf rica.org/publications/african-transformation-report-2017/african-transformation-report-2017/.

${ }^{19}$ Fox, L., Thomas, A. H., and Haines, C., 2017. Structural Transformation in Employment and Productivity: What Can Africa Hope For? Washington: International Monetary Fund, p. viii.
} 
sector has stagnated in output and employment terms. The latter happened in an environment of an unproductive agriculture sector and an employment intensive, urban-based informal retail sector. ${ }^{20}$

The authors then caveat their conclusion by pointing out that most of the new jobs, 'were created in sectors with low-productivity levels, such as subsistence agriculture and low value-added services. Self-employment has continued to be predominant'. ${ }^{21}$

Given the size of the informal sector and the nature of work in Africa, the key question when looking to the future of work is if digitisation will help to more rapidly formalise African economies and accelerate employment growth, with all the associated benefits listed above?

\section{Automation and the Threat to Work}

Estimates about the impact of the fourth industrial revolution, robots, the digital economy and automation differ hugely and include alarmist forecasts about the destruction of up to $30 \%$ of all jobs globally by 2030 . This is highly unlikely. In fact, the rich world, Europe and North America in particular, is enjoying an unprecedented bonanza of jobs, facilitated, of course, by their shrinking labour force as a portion of the total population. And, instead of the exploitation of low-end workers, workers are being upskilled and wages are generally rising. ${ }^{22}$

With each successive industrial revolution, technology has created many more jobs than it has destroyed. Despite the hype around artificial intelligence, robotics and automation, it is doubtful that the fourth industrial revolution will change this broad trend. The question we need to answer, though, is where these jobs will be created-in the developed or developing world, in Africa or in Asia? Remember that the capital and labour intensity of manufacturing is declining, i.e. less capital and less labour is required to produce the same value of goods and that technology (or knowledge) is globalising. Although knowledge does not translate into know-how (that requires practice and repetition), in theory someone with a fast enough internet connection in the Central Africa Republic has access to many of the

\footnotetext{
${ }^{20}$ Bhorat, H., Kanbur, R., Rooney, C., and Steenkamp, F., 2017. Sub-Saharan Africa's Manufacturing Sector: Building Complexity, Working Paper Series $N^{\circ}$ 256. Abidjan: African Development Bank.

${ }^{21}$ Abdychev, A., Alonso, C., Alper, E., Desruelle, D., Kothari, S., Liu, Y., Perinet, M., Rehman, S., Schimmelpfennig, A., and Sharma, P. 2018. The Future of Work in Sub-Saharan Africa. Washington: International Monetary Fund, p 1.

${ }^{22}$ The Economist, 2019. The Feature Is Entitled the Great Jobs Boom, 25 May.
} 
same knowledge resources as a consultant in Brussels. And the tools available through YouTube and other sites enable someone building a house in Lagos to teach himself to do the entire electrical wiring and installation, if perhaps not entirely safely.

Artificial intelligence, robotics and automation will have very different impacts in the developing world compared to the developed world, largely because robotics present a huge threat to higher-paid routine labour in the more mature countries. Although, as with every previous industrial revolution, new jobs will emerge that will replace the jobs lost to robots and automation. These developments will occur at every level and would, in some instances, appear to threaten large communities. For example, as China transitions to electric vehicles and the rest of the world follows, millions of established jobs associated with the internal combustion engine will eventually become redundant, to be replaced by skill requirements related to electric engines, battery storage and energy management systems. The question is only if the current crop of workers will be able to reskill or not. Similarly, as countries transition from coal to renewables as the dominant source of energy, thousands of coal miners in places such as Mpumalanga in South Africa will lose their jobs. But thousands of more new jobs will be created across the country as distributed wind, solar and biomass energy sources come online. Work, the saying goes, fills the time available. ${ }^{23}$

The largest potential for robot-based automation is in those states with large and well-paying manufacturing sectors like Germany, Japan, South Korea, the USA and increasingly China. The automation of low-wage and light manufacturing jobs, such as those generally found in Africa, seems much less likely in the foreseeable future. According to the African Development Bank:

So far, robotization has had only a small effect on most developing countries, where mechanization continues to be the predominant form of automation. Despite the hype surrounding the potential of robot-based automation, today the use of industrial robots globally remains quite small and amounts to less than two million units. Industrial robots are concentrated in the automotive, electrical and electronics industries, and in a small number of countries. ${ }^{24}$

According to UNCTAD:

\footnotetext{
23Sharma, R., 2016. The Rise and Fall of Nations-Ten Rules of Change in the Post-crisis World. New York: Penguin Random House, p. 56.

${ }^{24}$ Monga, C., 2017. Industrialization: A Primer. In: Industrialized Africa-Strategies, Policies, Institutions, and Financing. Abidjan: African Development Bank Group, p. 10.
} 
job displacement by robots is economically more feasible in relatively skillintensive and well-paying manufacturing, such as the automotive and electronics sectors, than in relatively labour-intensive and low-paying sectors, such as apparel production.... Indeed, the countries currently most exposed to automation through industrial robots are those with a large manufacturing sector that is dominated by industries which offer relatively well-paying jobs, such as automotives and electronics. By contrast, robotisation has had a relatively small direct effect in most developing countries so far, and this is unlikely to change in the foreseeable future, given their lack of diversification and technological upgrading 25

According to mainstream analysis, the demand for jobs that cannot easily be replaced by robots, especially those that require non-routine cognitive and socio-behaviour skills, will increase; such as managing teams, nursing and cleaning. However, the demand for routine, job-specific skills, such as those required for processing payroll, bookkeeping or assembling goods, will fall. And jobs that combine different skill sets will increase. As a result, global value chains are becoming more knowledge-intensive and low-skilled labour is becoming less important as a factor of contribution compared to capital and technology. ${ }^{26}$ The demand for labour is increasingly away from lowskilled to semi-skilled and skilled labour and it is for this reason that more and better education is so important for Africa.

A 2017 report by McKinsey estimates that less than 5\% of occupations are candidates for full automation and that the 'correct' lense through which automation should be viewed is that of tasks, not occupations or jobs. ${ }^{27}$ Even so, care work that requires empathy and judgement (such as nurses and elderly care), are harder to automate and are likely to increase as populations around the world age. So people will have to transition from one set of skills that may be replaced by automation to another, where that threat is not as acute. This is clearly less of a challenge in Africa, where employment is less formal and structured than elsewhere.

Technology by technology and job by job, there will be continued progress-and it will differ hugely between countries at different levels

\footnotetext{
${ }^{25}$ United Nations Conference on Trade and Development, 2017. Trade and Development, Beyond Austerity: Towards a Global New Deal. New York and Geneva: United Nations Conference on Trade and Development, p. ix.

${ }^{26}$ Lund, S., Manyika, J., Woetzel, J., Bughin, J., Krishnan, M., Seong, J., and Mac Muir. 2019. Globalization in Transition: The Future of Trade and Value Chains. New York: McKinsey Global Institute, p. 2.

${ }^{27}$ Manyika, J., Chui, M., Miremadi, M., Bughin, J., George, K., Willmott, P., and Dewhurst, M. 2017. Harnessing Automation for a Future That Works. [Online] Available at: https://www.mckinsey. $\mathrm{com} /$ featured-insights/digital-disruption/harnessing-automation-for-a-future-that-works.
} 
of development. In Japan and Germany that have highly paid and scarce workers, many of whom work in the automotive industry, a higher percentage of additional work could be automated. However, in many parts of Africa new jobs could be created at much lower start-up costs due to the reductions in the capital costs and lower barriers to entry referred to previously. ${ }^{28}$

In view of these considerations, and contrary to the trepidation with which the fourth industrial revolution is viewed in Europe and North America, the view from Africa is positive since progress, coming from a low base, offers prospects for a degree of catch up and because of the expectation that it would create more jobs in the formal sector.

A recent study by ACET that included extensive field work in eleven African countries found that less than a fifth of survey respondents thought the fourth industrial revolution would have a negative impact on jobs. In fact, the vast majority were excited about its positive impact.

The sectors seen as most positively affected by 4IR [fourth industrial revolution] technologies are software development, information and communication technology (ICT), and infrastructure - not surprising since 4IR will create demand for jobs in these sectors. But agriculture, finance, manufacturing, retailing, and tourism are also seen as benefiting from 4IR; the informal sector is seen as deriving the least benefit from $4 \mathrm{IR} .^{29}$

In this vein, a report entitled The Future of Work prepared for the European Commission concluded as follows:

The world of work is part-and-parcel of the changing economy, heavily influenced by globalisation, international value and supply chains, more division of labour, and digital disruption. Work is no longer a static concept but an umbrella term for roles performed in a different manner and under different legal arrangements. ${ }^{30}$

\footnotetext{
${ }^{28} \mathrm{McKinsey}$ estimates that across 46 countries (mixture of developing and developed economies) it looks as if by 2030 a range with a midpoint of $16 \%$ of occupations will have been automated and dislocated by automation. That number has a very large range and can go from very little to $30 \%$ since it depends on the rate of adoption, nature of the country and wage dynamics in the various sectors in that country. One can expect that in advanced economies it would be higher, say $20 \%$, whereas for developing countries the midpoint will be much lower since wages are lower. McKinsey podcast What is the future of work?, 1 December 2017.

${ }^{29}$ The African Center for Economic Transformation, 2017. African Transformation Report 2017: Agriculture Powering Africa's Economic Transformation. Ghana, p. 2.

${ }^{30}$ European Commission, 2016. The Future of Work Skills and Resilience for a World of Change. EPSC Strategic Notes, Issue 13, p. 11.
} 
Instead of workers being replaced completely by machines, the more likely future is where people work next to highly productive machines with the one augmenting the other. This is already evident in the way in which ICT is penetrating modern life through the use of smartphone applications to augment or ease the completion of everyday tasks.

Therefore the impact of the digital economy in OECD countries where we see the reshoring of the provision of goods and top-end services will include a trend towards short-term contracts and part-time work, although the vast majority of workers in the EU, for example, are still on full-time contacts. In addition, the Commission believes that automation will reduce routine job opportunities, such as those on a typical assembly line, in the formal sector. ${ }^{31}$

Yet, in a certain sense Africans might find this an easier transition, since Africans in the formal and informal sector often already juggle a number of part-time jobs. According to The Future of Work report:

work' is increasingly becoming an umbrella concept for tasks performed under different legal, functional and geographic frameworks. Jobs are being broken down into projects that may either be outsourced to independent professionals and experts, or be reconfigured into assignments that assemble physical or virtual teams, across borders and time-zones ${ }^{32}$

The trend towards the so-called gig economy or internet employment, which is characterised by freelance, on-demand work, is the latest manifestation of this greater fragmentation of work. The impact of COVID-19 is that many countries adopted lock-down strategies, forcing many employees to work remotely, providing a huge boost to the gig and off-site work. In the gig economy independent workers are hired for short-term tasks, often via online work platforms which pays them for each transaction or 'gig' they complete. At high levels of complexity and value, the gig economy is about digital technologies enabling geographically dispersed teams, who often come from different countries, to be assembled around a given project. ${ }^{33}$ Although still quite small in much of Africa (at less than $0.3 \%$ of the active labour force) it is burgeoning especially in on-demand services ranging from the delivery

\footnotetext{
${ }^{31}$ Ibid., p. 4.

${ }^{32}$ Ibid., p. 2.

${ }^{33}$ Africans in the informal sector do not have much job security and global developments such as the gig economy appear to now also shift the risk of employment steadily to the employee in an environment where there are little or no social safety nets such as unemployment benefits and where unions are weak meaning that employees have less bargaining power, opening up the potential for job insecurity and greater wage differentials. European Commission, 2016. The Future of Work Skills and Resilience for a World of Change. EPSC Strategic Notes, Issue 13, p. 2.
} 
of fast food to more sophisticated tasks such as accounting and editing. ${ }^{34}$ But even in the USA, the gig economy accounts for only around one percent of jobs. $^{35}$

The interesting thing about the notion of the gig economy is that it is already a much wider reality in Africa, although in a different form. Many entrepreneurial Africans in countries like Kenya already hustle to keep bread on the table by doing any number of jobs, tasks and functions in a seamless and often informally structured work environment. What will surely follow would be innovations that will provide safety nets such as unemployment insurance, health care and the means to cover various risks. The fourth industrial revolution is unlocking opportunities for millions of self-employed that did not previously exist.

It is therefore unlikely that we will witness widespread automation in subSaharan Africa. The region's large-scale informal economy and lack of the necessary digital infrastructure currently precludes such a development since low pay levels mean that labour will remain cheap.

\section{The Impact of Digitisation in Ghana}

Repeat visits to Accra in Ghana over the past two decades has made me a witness to the amazing political and developmental revolution that is taking place there, which is reflective of many other African states, and to consider its potential for job creation and progress.

By African standards, Ghana has a small population of around 30 million people. It is more urbanised than most African countries (close to 60\%), allowing for a more rapid transition to digital services, and also making it easier to provide water, sanitation and other services. By 2040 almost 70\% of its citizens will live in urban areas-a huge advantage that will allow for rapid economic growth. This could eventually allow Ghana to graduate from its current low middle to upper-middle-income status.

Partly because of higher-than-average rates of urbanisation, the total fertility rate (currently at four children per woman) is declining rapidly and Ghana will enter its demographic sweet spot earlier than most West African countries, in around 2035. Thereafter the positive ratio of working-age persons to dependents should ensure even more rapid growth rates-provided

\footnotetext{
${ }^{34}$ Mo Ibrahim Foundation, 2019. Africa's Youth: Jobs or Migration? London: Mo Ibrahim Foundation, p. 46.

${ }^{35}$ The Great Jobs Boom, in The Economist, 25 May 2019.
} 
that Ghana manages to sustain the progress it has demonstrated towards inclusive, democratic governance over the last decade.

On a recent trip to the country in December 2018, I was invited to speak at a conference on the future of work in sub-Saharan Africa that was hosted by the IMF. Terminal 3 at Kotoka International Airport is gleaming and brand new, a far cry from the colonial-era building that had served as a sorry excuse for an international airport for so many years.

Officials are smart, courteous and clearly proud of the new facility. The construction was done by the Turkish construction company, Mapa Construction MNG Holding, cost US $\$ 400$ million and is unpretentious, solid and well maintained-in contrast to many of the Chinese constructions elsewhere.

At the opening session of the IMF conference in a swanky Accra hotel, Ghana's vice president Mahamudu Bawumia set out the country's plans to leapfrog its development by using information and digital systems. In 2012 Ghana introduced Biometric Voter Registration and since May 2018 a smart national ID system (dubbed Ghana Card) that uses biometrics is being rolled out (free of charge to all Ghanaians). This is being done region by region and before the end of 2019, it will provide each Ghanaian with a unique personal identification number or PIN.

Hereafter a smart national ID will be a requirement to open a bank account, apply for a passport or driver's licence, to register a SIM card, buy property, register a business or even to enroll children in school (children are linked to the ID of their parents). Globally nearly a billion people lack any type of legally recognised form of identification, without which it is impossible to access banking, government benefits, education and many other critical services. ${ }^{36}$

Exports or imports are directly linked to the PIN to eliminate fraud and theft in the shipping and clearing of goods at ports and harbours. Already the number of agencies required to inspect a container has been reduced from 16 to just three, which cuts a lot of red tape.

Furthermore, the PIN will be used to verify a person's identity during job searches and applications, for e-tickets at airports, at border crossings, police checkpoints and the like. It will eventually become mandatory for the validation of payments, particularly electronic payments.

Most importantly, an ID number allows large portions of the informal sector to be brought into the formal economy. This is a huge leap forward

\footnotetext{
${ }^{36}$ The World Bank, 2019. Identification For Development (ID4D) Global Dataset. [Online] Available at: https://datacatalog.worldbank.org/dataset/identification-development-global-dataset.
} 
in a country like Ghana that has, until recently, had no comprehensive identity system. It is also occurring at a pace that would astound bureaucrats in China and Western countries, where such systems were originally rolled out manually and with great effort over several decades.

In addition, the GhanaPostGPS will provide a unique digital address for each $5 \times 5$ meters of land area in a country that previously had no formal system of finding a specific location without local knowledge. Armed with a digital address, small and informal businesses can now register for a bank account and access credit. It basically means that anyone with a phone technically has a bank account.

The GhanaPostGPS app comes with other functions as well, such as panic buttons for emergency communication to the police, fire and ambulance services. ${ }^{37} \mathrm{~A}$ unique digital address will allow door-to-door delivery of literally everything. For example, the country will shortly start with the delivery of emergency medical and other supplies by drone. Here Ghana is copying the example of Rwanda where this has been done for some time (they used corporate social responsibility funds for the initiative).

Besides many other benefits, these innovations will improve tax collection since both informal and formal businesses will steadily be forced to use electronic payment systems that are all part of the formal economy, increasing government revenues. This will again enable the state to deliver other services such as education, roads, water and sanitation.

Soon Ghana will also have a fully digital platform for the payment for all government services, including smart driver's licences and digital car registration. Moreover, Ghana is busy with the digitisation of land ownership. By the time that this book is published it should have a new base map survey (the first since 1974) that uses blockchain technology to secure and verify the ownership of all land. Furthermore, with the support of the World Bank the Ghanaian Ministry of Education is adopting modern technology by delivering its lessons through the use of e-learning technology. ${ }^{38}$

Modern technology also allows for better policing of something like mining licenses, for example. In many African countries, including in South Africa and the Democratic Republic of the Congo, illegal mining is rife, where it is often done by foreigners who mine at night in extremely dangerous

\footnotetext{
${ }^{37}$ See unique, digital addresses for all locations across Ghana at: GhanaPostGPS, 2019. My Digital Address. [Online] Available at: https://www.ghanapostgps.com/.

${ }^{38}$ The intelligence Box (iBox) is a home-grown proprietary technology for the delivery of premium, curricular-specific, educational content for Senior High School (SHS), Junior High School (JHS), and non-formal and skills training: B\&FTonline, 2018. Out of the Box. [Online] Available at: https://the bftonline.com/2018/opinions/investing-in-human-capital-innovation-and-knowledge-with-the-ibox/.
} 
conditions. Already 150 drone pilots have been trained to monitor illegal mining across Ghana.

In recognition of these efforts Google opened its first African Artificial Intelligence (AI) research centre in Accra, bringing together top machine learning researchers and engineers dedicated to AI research and its applications. The centre will work with local universities and jointly with a small number of other centres in Paris, Zurich, Tokyo, Beijing, Montreal, Toronto, Seattle, Cambridge / Boston, Tel Aviv / Haifa, New York, and the Google headquarters in Mountain View, San Francisco. ${ }^{39}$

This is an example of what is possible in a future Africa where the demand for new services are met and job opportunities for young people in urban areas are unlocked.

\section{The Promise of Greater Economic Formalisation in Ghana}

Using the IFs forecasting platform, I find that the size of Ghana's economy increases by roughly US $\$ 0.7$ billion dollars (in PPP) over the first ten-year period for every one percent decrease in the size of the informal sector as a portion of GDP. And the benefits just keep on growing. In other words, if Ghana could use digitisation to draw people into the formal sector and hence reduce the size of the informal economy as a portion of GDP by five percentage points from 2020 to 2030 , it would gain US\$4.6 billion in the size of its economy by 2030 and US $\$ 14$ billion by 2040 .

A larger economy translates into higher average incomes and the result is an increase of US $\$ 140$ average annual income per person above the Current Path forecast by 2030 for each of Ghana's 38 million citizens, and US $\$ 340$ by 2040, at which point Ghana would have 45 million people. That is an enormous improvement. Other livelihood improvements that follow are decreases in poverty and inequality.

The 2019 report on Africa by the United Nations Commission for Africa (UNECA) finds that in the long-term government revenue on the continent can be increased by $12-20 \%$ of GDP through the rigorous pursuit of tax and non-tax income collection, which is possible through digitisation. Leveraging digital systems to increase revenue collection through e-taxation increased revenue collection in Rwanda by six percent of GDP. South Africa

\footnotetext{
${ }^{39}$ Adeoye, A., 2019. Google Has Opened Its First Africa Artificial Intelligence Lab in Ghana. CNN. [Online] Available at: https://edition.cnn.com/2019/04/14/africa/google-ai-center-accra-intl/ index.html.
} 
used online tax payments to reduce compliance costs and the time to comply with the value-added tax by $22 \% .{ }^{40}$

Technology also enables the documentation of vital events in a person's life (live births, adoptions, legitimations and recognitions, deaths, marriages, divorces, separations and annulments) that are fundamental to having a legal identity and guaranteeing human rights and access to public services. It can provide access to finance, information about health, and offers a way to educate and connect people. ${ }^{41}$

The analysis on the potential positive impact of a more rapid formalisation of Ghana's economy corresponds broadly with the gist of an article by Amolo Ng'weno and David Porteus in a contribution for the Center for Global Development. ${ }^{42}$ The authors argue that the explosion in digital platforms is slowly changing the nature of what it means to be in the informal or formal sector. The result is the incremental formalisation of the latter through a process of digital business progression where each small step is low cost and low risk. Instead of being casual labour, many workers who are active in the informal economy already live in the gig economy.

In the short-term, it looks like technology is going to create a set of new opportunities in the gig economy: shared-ride drivers, homestay hosts, e-commerce logistics, e-commerce sellers, and small-scale e-commerce producers. These will be supplemented by an army of 'digital translators'. ... As an economy digitizes, more people are needed to help the customer and the citizen transition into the digital economy. Most of these translators work on commission and set their own hours. ${ }^{43}$

On the future nature of work, they write that 'it's time we recognized the truth about the future of work in Africa ... it isn't in the growth of full-time formal sector jobs. The future of work will be people working multiple gigs with "somewhat formal" entities'. ${ }^{44}$

\footnotetext{
${ }^{40}$ United Nations Economic Commission for Africa, 2019. Fiscal Policy for Financing Sustainable Development in Africa. Addis Ababa: UNECA, p. 113.

${ }^{41}$ Ibid, p. xiii.

${ }^{42} \mathrm{Ng}$ 'weno, A., and Porteous, D., 2018. Let's Be Real: The Informal Sector and the Gig Economy are the Future, and the Present, of Work in Africa. [Online] Available at: https://www.cgdev.org/publication/ lets-be-real-informal-sector-and-gig-economy-are-future-and-present-work-africa.

${ }^{43}$ Ibid.

${ }^{44}$ Ibid.
} 
Eventually, 'in Africa, as elsewhere, the future of work will depend on the battle between automation and innovation', argues the Mo Ibrahim Foundation. 'While automation leads to a decline in employment in old sectors, innovation makes new sectors or tasks possible. 45

Of course the gig economy doesn't only have positive effects. Generally the impact of digitisation is to lower barriers to entry and increase competition. In Africa this could however further force down wages and increase the number of people engaged in informal and unregulated work. The gig economy is therefore likely to result in precarious or insecure work with lower job and income security, poorer working conditions and lower social protection coverage when compared to employees in standard employment relations. But even that is not a given. Business innovation and government intervention is sure to fill this gap.

Then again digital technologies could make a huge contribution to help formalise African economies. I will explore this point further in Chapter 10 as part of a discussion on the continent's ability to benefit from digitisation and to leapfrog into the future thanks to the fourth industrial revolution.

\section{Conclusion: Thinking Differently About the Future}

On the current trajectory, the growth in the African labour force will far outstrip the supply of jobs, leaving many of the continent's citizens destitute, frustrated and dependent on the informal sector to survive. This will make some of them eager to migrate elsewhere in search of opportunities including to neighbouring Europe which seems particularly fixated on this challenge above all others. These conclusions re-emphasise the importance of an agricultural and manufacturing revolution that would increase growth and employment.

Only if one views employment in Africa through the lens of selfemployment (much of which occurs within the informal sector), digitisation and the fourth industrial revolution does it become possible to think differently about the future of work in Africa. With large numbers of youth entering the labour market, the demand for formal sector jobs in Africa is huge and steadily increasing. However, previous chapters have also indicated that Africa's labour force generally lacks many of the purported enablers

\footnotetext{
${ }^{45}$ Mo Ibrahim Foundation, 2019. Africa's Youth: Jobs or Migration? London: Mo Ibrahim Foundation, p. 44.
} 
for rapid job creation, such as adequate health and appropriate basic infrastructure (Chapter 3), and minimal levels of education and the right skills (Chapter 6).

A large cohort of young people with improving levels of education that are either unemployed or eaking out a survival in the informal sector could be a destabilising force both in Africa and in the neighbourhood. Young Africans are increasingly connected with one another and the rest of the world through the internet and social media and will not stop seeking out the opportunities and lifestyles their peers have in the developed parts of the world.

Chapter 12 deals with the structural drivers of instability, including the combination of youth and unemployment. In a different context this group coincides with the NEETS - the large group of Africans Not in Education, Employment or Training. Clearly the orientation of education opportunities towards the actual opportunities or needs within the economy, vocational training in particular, could assist in lowering the political temperature. In addition, there is the potential for job creation in agriculture, light manufacturing, modern services, tourism and creative industries.

Since much of Africa's growth is going to come from commodity exports it is equally incumbent upon governments to raise incomes through commodity value addition and to find ways of extending the value chains of the capitalintensive projects such as the gas projects in northern Mozambique into the domestic economy. Furthermore, governments have to find ways of enhancing productivity and improving working conditions and regulations to reduce workers' vulnerability.

There will also be an important role for the public sector in creating jobs for social development and through public works programmes, both to improve livelihoods and enhance skills.

Most concerning is that the vast number of Africans that survive in the informal sector appear unable to overcome the hurdles created by the fourth industrial revolution. This underlines the importance of using digitisation to open up new opportunities for this group, such as access to finance and bringing the informal sector into the mainstream. Every effort should be made to overcome the segregation between the formal and informal sectors through productive linkages and by reforming laws and regulations.

In this chapter I used the example of Ghana to illustrate how modern technology could potentially formalise its economy more rapidly. I provided an indication of the results using economic growth, poverty and GDP per capita. By following this example, African governments can harness the potential of digitisation to formalise and empower portions of the informal economy 
and empower ordinary citizens with access to finance, education and opportunity. Digitisation can help with the modernisation of agriculture and lift smallholder farmers out of poverty, but only if governments and leaders are aware of the opportunities it offers and develop effective digital strategies that support local innovation firms to compete and invest in ICT. Many Africans will still be working on subsistence farms or struggling through various forms of informal employment. The future of employment for those people will be just as impacted by climate change as it will be robots. For them it will be very similar to how work looks today, with some improvements and changes.

To provide sufficient meaningful work the continent needs a shift in mindset that would allow a speedier escape from poverty compared to the slow progress envisioned under the Current Path forecast. This change in mindset can be captured as a change from consumption to production and towards innovation, community self-sufficiency and independence.

Only if African governments are able to create a culture of entrepreneurship will the continent be able to reduce unemployment. Attitudes need to change from 'getting education to get a job', to 'getting education to create jobs and opportunities'. Even then, such entrepreneurship and selfemployment will make only a small contribution to employment rather than solving the unemployment challenge.

The next chapter builds on these findings to explore the potential of technology to allow Africa to leapfrog towards a better future.

\section{Further Reading}

African Development Bank. 2020. African Economic Outlook 2020: Developing Africa's Workforce for the Future, 30 January 2020. https://www.afdb.org/en/ documents/african-economic-outlook-2020.

Global Commission for the Future of Work. January 2019. Work for a Brighter Future. International Labour Organisation. https://www.ilo.org/infostories/enGB/Campaigns/future-work/global-commission\#intro.

Graham, M., Hjorth, I., and Lehdonvirta, V. 2017. Digital Labour and Development: Impacts of Global Digital Labour Platforms and the Gig Economy on Worker Livelihoods. Transfer: European Review of Labour and Research, 23(2), pp. 135-162. https://doi.org/10.1177/1024258916687250.

International Labour Organisation. Abidjan Declaration on the Future of Work in Africa, December 2019. https://www.ilo.org/wcmsp5/groups/public/—ed_norm/ —relconf/documents/meetingdocument/wcms_731646.pdf. 
Open Access This chapter is licensed under the terms of the Creative Commons Attribution 4.0 International License (http://creativecommons.org/licenses/by/4.0/), which permits use, sharing, adaptation, distribution and reproduction in any medium or format, as long as you give appropriate credit to the original author(s) and the source, provide a link to the Creative Commons license and indicate if changes were made.

The images or other third party material in this chapter are included in the chapter's Creative Commons license, unless indicated otherwise in a credit line to the material. If material is not included in the chapter's Creative Commons license and your intended use is not permitted by statutory regulation or exceeds the permitted use, you will need to obtain permission directly from the copyright holder.

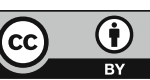

